\title{
Transitivity, paradigmatic choices, and thought presentation: A stylistic analysis of Joyce's Eveline
}

\author{
Bonifacio T. Cunanan
}

Department of English, College of Arts and Letters, Bulacan State University, City of Malolos 3000, Philippines

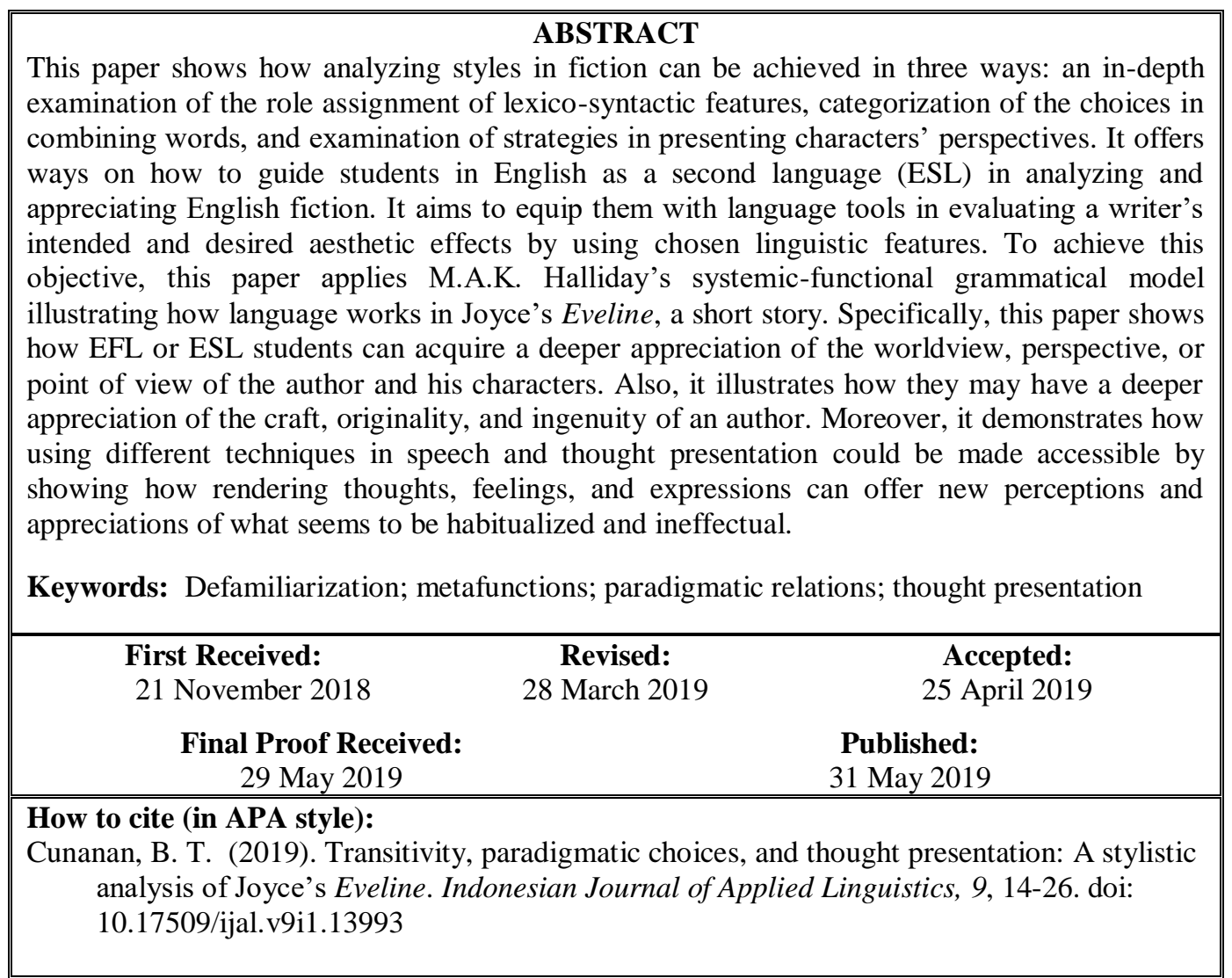

\section{INTRODUCTION}

Stylistics deals with the methods and procedures in demonstrating how language works in different texts, either literary or non-literary. It is an enabling tool that empowers students to respond appropriately to different situations in which they can apply the sociological dimensions in appraising the nuances of language. The application of stylistics is wide-ranging that encompasses several genres including but not limited to literary works, propaganda materials, the language of the mass media, legal instruments, and print advertisements. The inability or lack of familiarity of an ESL or EFL teacher in using a linguistic model in analyzing texts such as those in the foregoing examples will render the effort into a mere literary analysis. Gonzales and Flores (2016) acknowledge stylistics as an emerging discipline that may provide the students with some new ways of appreciating literary texts. Similarly, in acknowledging the link between language and literature, Amase, Tsavmbu, and Kaan, (2014) stress the potential of stylistics in having a more critical stance in how the two confluence each other.

The indispensability of the connection between language and literature in analyzing literary texts has been established for some time. In his Closing Statement: Linguistics and Poetics in Conference on Style at Indiana University in 1958, Jacobson laid an enduring statement which has become "the 'touchtone' epigraph for modern stylistics" (Simpson, 2012). In the conference, Jakobson stated, "a linguist deaf to the poetic function of language and a literary scholar indifferent to linguistic problems and unconversant with linguistic methods are equally flagrant anachronisms" (Sebeok, 1960; Weber, 1996). Such an assertion has reinforced the complementation of language structures and literary devices in teaching stylistics. In addition, 
the statement suggests that the teaching of literature can be made more interesting and effective if it is linguistically informed.

Teaching literary analysis and appreciation, with its inherent subjectivity, can be daunting to both teachers and students, but such a task can be made more dynamic, meaningful, and interesting with the classroom applications of poetic functions of language which, to Fowler (1984), is an integral part of linguistics. Violetta-Irene (2015) discovered that the complementation of language and literary texts might result in a lively and motivating activity. Such a statement confirms that students who use authentic texts with peer collaboration improved their language abilities (Tunçel, 2009). To illustrate the efficacy of stylistics in a language and literature class, the present study examines the uses of transitivity, paradigmatic choices, and thought presentation in exploring and expounding the theme in Joyce's (1991) Eveline.

This short story is about the protagonist's dilemma. Eveline, seated at the window, is watching the avenue as the evening comes. She is torn between staying home or eloping with her fiancé. She is thinking whether she stays with the people whom she has known and loved all her life or choose to be with Frank in going to Buenos Aires to start a new life. But she has made a promise to her deceased mother: to keep the house together and take care of her father and her siblings. While thinking of her home and reviewing all its familiar objects, she is reminded of her uncaring, abusive, and violent father. She thinks that it is right the time to be on her own. However, nothing in her is certain but apprehension. In her mind, there seem to be two persons quarrelling. She wonders whether there a guarantee that Frank will love her forever and whether she will be happy with Frank in a distant and unknown country. She also has no idea whether her siblings will take her decision of turning her back on them. She also worries about people's perceptions, especially her coworkers, of her. At the end of the story, the protagonist, while at the pier with Frank, is like a helpless animal, with her face white and "her eyes give Frank no sign of love or farewell or recognition" (Joyce, 1991, p.36). Her failure to resolve her personal issues is significant in finding the overarching theme of the story.

To illustrate how Joyce has established paralysis as the theme of the story, this study aims to answer the following questions: (a) How may transitivity be explored in the story by way of analyzing the different assigned semantic roles? (b) How may paradigmatic choices be explored in exemplifying the persona's point of view? (c) How may the Free Indirect Discourse (FID) in thought and speech presentation describe the blend between transitivity roles and lexico-syntactic choices?

\section{Stylistics in language and literature pedagogy The importance of literature in a language class}

Even though Gower (as cited in Edmondson, 1997) has downplayed the use of literary texts in language classes for lack of observable evidence, still many language and literary scholars adhere to the Jacobson's groundbreaking statement in 1958. Along with this stance, several works acknowledge the complementation of language and literature. For instance, Hall (2005), has stressed the usefulness of literature in language education. Also, Carter and Long (1991), Choudhary (2016), Collie and Slater, (1987) and Lazar (1993) have acknowledged that literature promotes motivation in the classroom. Fowler (1984) has also articulated the relevance of literature in which texts help in explaining how language contextualizes both social and cultural dynamics. Literature, according to Gaies (1979) and Widdowson (1975), can motivate students and help them develop better reading skills. The use of literary texts, Koutsompou (2015) has reported, can make language classes livelier and motivating. In the same way, Povey (1972) argued that literature increases language abilities such as "extensive and subtle vocabulary usage" and "complex and exact syntax" (p. 187).

In ESL and English as a foreign language (EFL) contexts, Watson and Zyngier (2007, p.4) have noted that the "use of literary texts is often advocated to enhance proficiency in reading, vocabulary growth, and cultural knowledge." To enhance students' acquisition of better language skills, Santhi (2012, p.21) believes that "teachers should focus not only on linguistic but also on literary and cultural elements." Literature can also help in the holistic development of the learners for it nurtures the capability to empathize with others (Rosenblatt, 1995). It also helps in establishing an acceptable variety of language in use (Cox, 1991; West, 1994).

The foregoing arguments underscore that using language as a springboard to literature teaching has opened many opportunities for English literature and language teachers to be creative in their teaching by introducing the stylistic approach in their classrooms (Gonzales \& Flores, 2016). To this end, Van (2009) discovered that the study of literature in EFL and ESL classes is very important because "it exposes students to meaningful contexts that are replete with descriptive language and interesting characters" (p.2).Such an observation has been found consistent with Hall's (2007) position, which emphasizes the need for understanding the importance of having stylistic intervention in language classrooms and curricula. Hence, the use of literary texts in ESL and EFL language classrooms, Hişmanoğlu (2005) has emphasized, can also help the reader acquire familiarity with the "underlying reasons and criteria for language teachers using and selecting literary texts" (p. 53).

\section{The importance of stylistics in teaching literature}

According to Maley (1989), in showing how to analyze literary works, teachers use stylistics to treat literature as text. In Short (1995), this approach makes the interpretation "explicit and retrievable" (p. 53). Devardhi and Nelson (2013) and Fogal (2015) acknowledge the importance of stylistics in enhancing 
the development of language proficiency and its role in raising language awareness that helps improve L2 performance. Also, stylistics may be used to encourage communication between the teacher and learners, and it may be applied to indirectly teach the four macro-skills in language. The stylistic approach also appears to show improved results in literature classes (Akyel, 1995; Fakeye \& Temitayo, 2013; Inyang, 2009). Moreover, Van (2009) has noted that stylistics can be used to explore literary texts to develop students' sensitivity to literature. In addition, Inyang (2009) has reported that stylistics may help EFL students improve their scores in literature tests. Similarly, Simpson (2004) and Verdonk (2002) have also described stylistics as contextualized and discourse-based, with a focus on issues of choices of style, register, genre, culture, and identities in varying contexts. Considering those above-mentioned criteria, stylistics and literary studies need to be understood within a broader context, a framework for sociolinguistic theory and method (Sivasubramaniam, 2006).

\section{The conceptual basis of the study The dual nature of language}

Language is an innate and inherent human characteristic, but its transmission is socio-cultural in nature. Although human beings are born with language, no one automatically learns how to read and write. These two language competencies should be taught and learned with attention to the features and conventions of writing. Even though it is not the primary characteristic of language, writing is important because it is needed in the preservation of culture, history, and civilization. Writing also plays an important role in the development of shared knowledge and identity of a community or a nation. Written records in history and literature are important in defining the identity of the people who produce and use them. Those reasons help in situating the place of literature in the curriculum. Dealing with class struggle, ethnicity, and gender sensitivity, literature also helps in promoting a sense of idealism and virtues. In addition, it gives students the opportunity to have an in-depth appreciation of language in relation to dynamic human conditions.

Literature, like other registers, needs a distinct use of language. It demands that readers need to have some degree of knowledge on structures and functions of language. Pathan and Al-Dersi (2013) have acknowledged that comprehension is an indispensable part of literary appreciation, and it takes a significant role in teaching and learning the intricacies and peculiarities of the target language. In this regard, several studies (Arnold, 2009; Bell, 2013; Omaggio Hadley, 2001; Silberstein, 1994; Shrum \& Glisan, 2010) are in one accord in showing that reading any type of text, literary and non-literary, both in a second language and a foreign language can be a challenging task because as students advance in their language study, they will also be required to read more and more in the target language. On this view, Arnold (2009) recognizes that learners consider reading in the EFL as "laborious, unpleasant, and ultimately unsuccessful" (p.340). Hence, they need to be guided and helped to achieve their learning goals.

\section{Contextualizing language through literature}

In 2007, the Modern Language Association (MLA) Ad Hoc Committee on Foreign Languages issued a report that advocates for a broader approach to teaching EFL "in which language, culture, and literature are taught as a continuous whole" (MLA, 2007). Bell (2013) reported that MLA advocated for a curricular approach to EFL classes that combine language and content which help in developing students' basic knowledge of the literature of the target language and culture while it eases comprehension of literary works written in the target language. Shrum and Glisan (2010) stress that with good planning, teachers can instil enthusiasm in reading. Upreti (2012) also reported that students find reading literature challenging, particularly in (a) comprehending the plot, (b) comprehending the characters, (c) understanding the role of the narrator, and (d) using the student's language background. Similarly, Upreti (2012) says that short stories can be challenging to teach because of, at least, the following challenging elements: vocabulary, language, structure, plot, moral, and character.

Analyzing literary works can be difficult for many ESL students, particularly modernist fiction. One characteristic of modernist fiction that ESL and EFL students may find challenging is the stream of the consciousness (SOC) technique. To Lončar-Vujnović (2013), the SOC technique places a psychoanalytical phenomenon at the center of modernist fiction, allowing readers to connect their thoughts with the flow of impressions passing through a character's mind. Lončar-Vujnović (2013) continues to describe this technique which makes it "impossible to separate the subject from the how style" as it deals with "categories of mental experiences: sensations, memories, imaginations, conceptions, and intuitions" (2013, p. 72).

James Joyce, according to Li (1999) and Wang (2014), is the forerunner of the SOC technique. He is also one of the most influential novelists of the 20th century, with the technique as his original contribution to contemporary fiction. In fact, Zhang considers him "second only to Shakespeare in his command of English" (1994, p. 202). Such a technique freely captures the passage of thought through the mind of the characters in fiction, making the sentences become longer, less organized, and more sporadic in style (Huang, 2014). With this modernist innovation, ESL and EFL students, consequently, need to be more familiar with the author's style and his milieu.

Suzuki (2001) stressed that the analysis of the grammatical features is useful to examine the author's style as the process constitutes various aspects of language. The complementation of surface (horizontal relations) and deep structures (vertical relations) in grammar as expressed in syntactic structures and 
semantic role assignments can be traced in the works of Jakobson. He expressed the complementation through "the axis of combination" and "the axis of selection" (Baldick, 2001, p. 255; Malmkjær, 1991; Malmkjær, 2002, p. 513). The axis of combination (syntagmatic) and the axis of choice (paradigmatic) are situated in Jakobson's theory of communication in which he identifies the six functions of language according to their different orientations: (a) addresser (emotive), (b) addressee (conative), (c) context (referential), (d) contact (phatic), (e) code (metalingual), and (f) message (poetic) (Halliday, 1978; Jakobson, 1960; Malmkjær, 1991, 2002; Norgaard, Busse, \& Montoro, 2010). In addition, studying literary texts in relation to the axes of combination and choice (paradigm and syntagm, respectively) leads to an appreciation of the writer's style considering that language works as "a discrete network of options" and serves social functions in the lives of the people who use it (Halliday, 1978, p.4).

\section{The linguistic dimension of style: Axes of combination and choice}

Style, both linguistic and literary, is one of the most contentious and controversial terms in literary studies. Leech (1969) described poetic language from the ordinary language in which the former "may violate or deviate from the generally observed rules of the language in many ways, some obvious, some subtle" (p. 5). Style, according to Traugott and Pratt (1980), is the writer's choice of using (or not using) available linguistic features to express a message either in a conventional or deviant manner, or departure from linguistic norms. This choice ranges from the phonological up to discourse features of the language, both structural and functional. In this regard, Fowler (2006) maintained that all texts manifest style, a standard feature of all language, a manner of expression, describable in linguistic terms, justifiable, and valuable in respect of non-linguistic factors. Fowler (2006) also argued that style depends on some set of selected features or surface structure of language such as phonological features or syntactic organization, the syntagmatic dimension of which is the linear aspect of language (Trask, 1993; Lee, 2006). This horizontal axis helps in creating an aesthetic impression among readers, making them feel an authorial or a certain period or milieu in expressing a thought. It is on the syntagmatic axis that words are linked together and connected according to grammatical rules (Malmkjær, 2002). Syntagmatic relations are phrasal associates and syntactic collocations (Şeker, 2013; Shaumyan, 1998). Traugott and Pratt (1980, p.169) explained, "meaning is expressed by means of syntax". Moreover, Blake (1990, p.11) recognized that the meaning of the message best starts with syntax, being "the heart of a text by exposing its structure". Figure 1 presents the axes of combination and choice: syntagm and paradigm, respectively.

Furthermore, it is on paradigmatic "vertical axis" in which choices about which words to link together are realized. A paradigm, according to Baldick (2001), is a set of linguistic or other units that can be substituted for each other in the same position within a sequence or structure. A paradigm, in this regard, is made up of all words that have the same grammatical function, the substitution of which by another set of words does not disturb the meaning of a sentence. To Baldick (2001) and Sahlgren (2006), paradigmatic relations hold between words that occur in similar contexts as well as relations in absentia. Trask (1993) elaborated that paradigmatic relations pertain to "any relation between two or more linguistic elements which are in some sense competing for possibilities, in that exactly one of them maybe selected to occupy some particular position in a structure" (p. 197).

In other words, the essence of an expression can be deduced not only from what the writer uses but also from the array of expressions that the writer could have used but intentionally or purposely replaced or displaced with other expressions, provided that the concepts belong only to the same grammatical category and do not disturb the syntax of the sentence. In considering the literary qualities of Eveline, the present researcher believes, that the said axes are crucial to both ESL and EFL students.

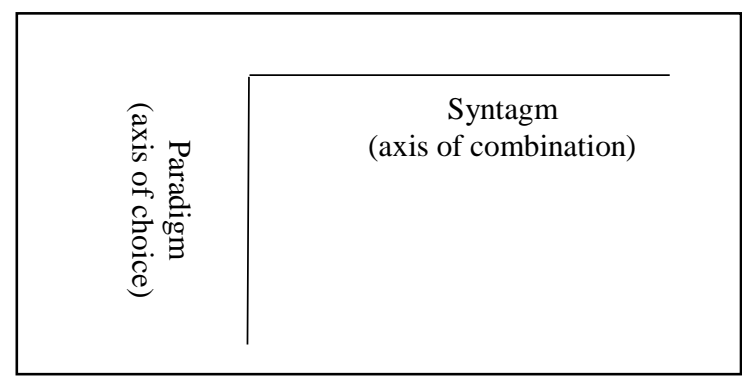

Figure 1. The syntagmatic and paradigmatic axes

\section{Style and thought presentation}

One concern of contemporary stylistics is to examine how writers transcribe the speech and thoughts of characters in fiction. In this regard, Simpson (2004, p.30) acknowledged the work of Leech and Short (1981) as "the most influential framework for the analysis of speech and thought representation in narrative fiction." Leech and Short (2007) listed eight types of speech and thought presentation, with Free Indirect Discourse (FID) as one of them. FID is used to blur the distinction between the voice and thoughts of the narrator and the voice and thoughts of their characters (Gunn, 2004). FID is a thoughtful presentation technique that allows third-person narration "slips in and out of characters' consciousness" that makes 'characters' thoughts, feelings, and words spontaneously flow through the third-person narrator in FID". Told by a third-person narrator, Eveline presents the protagonist's point of view using the narrative technique.

\section{Defamiliarization: A stylistic tool}

Another stylistic tool that has been used in the analysis of Eveline is defamiliarization. This tool, which is a 
deviation from linguistic norms, is one of the characteristics of literary language because it makes the familiar appear strange. Defamiliarization was coined by Shklovsky in 1917 (Malmkjær, 1991). From Russian ostranenie, defamiliarization is central in the arts, the function of which is "to make people see the world from a distinct perspective". To Fowler (1996, p.58), defamiliarization veers away from the habitualized, sterilized expressions by making the old and habitual to be spoken "as if it were new and unusual' and permits one to "speak of the ordinary as if it were unfamiliar." It is "the distinctive effect achieved by literary works in disrupting our habitual perception of the world" (Baldick, 2001, p. 62). Furthermore, the intended aesthetic effects can be achieved when some items in the text are used with unusual and "noticeable frequency" for some valid reason resulting in a cumulative "distinct effect" (Fowler, 1996, p. 95). This foregrounding technique or aktualisace is a characterization of thought process that is "fundamental characteristic of human perception" (Van Peer, 1986 as cited in Malmkjær, 1991, pp. 440-441). The present study considers the significance of defamiliarization and foregrounding in establishing the persona of the protagonist in Eveline.

\section{METHOD}

The three metafunctions in Hallidayan grammar were used in analyzing the syntactic structures and semantic role assignments in the text. Hallidayan grammar reappraises language as a system of choices (Matthiessen, 1995) and "a system for the expression of meaning” (Nunan, 2009, p. 9). This grammatical model underscores the inseparability of language and text (Halliday, 1985). From a semiotic perspective, Halliday (1978, p.39) stressed that language evolves as systems of "meaning potential" which permit speakers to negotiate meaning in context. Putting a premium on the semiotic dimension of communication of this framework, Malmkjær (1991, p. 141) noted that language could be viewed as an "instrument by means of which people can enter into communicative relations with one another." In this regard, this paper is consistent with Fowler's view that the codes of language may be used to interpret, organize, and classify aspects of discourse as reflections of reality. Fowler (1996) added, "literary texts do speak and participate in society's communicative practices and are important in influencing world view and social structure" (p.130). It is in this view that language provides metafunctions to realize to assist in our realization of context. Halliday (1970, 1978, 1994) calls these three metafunctions: (a) textual metafunction, (b) interpersonal metafunction, and (c) ideational metafunction.

\section{The three metafunctions}

The textual metafunction gives links between language and the features of the situation in which it is used. It pertains to the Theme-Rheme construction or the old and additional information, in which the former serves as the take-off of the sentence, and the latter, the trajectory. According to Halliday (1985), Theme includes the message in a text, indicating the identity of text relations. The topic comes first, and after that, Comment appears to expand, justify, and provide additional information to preceding information.

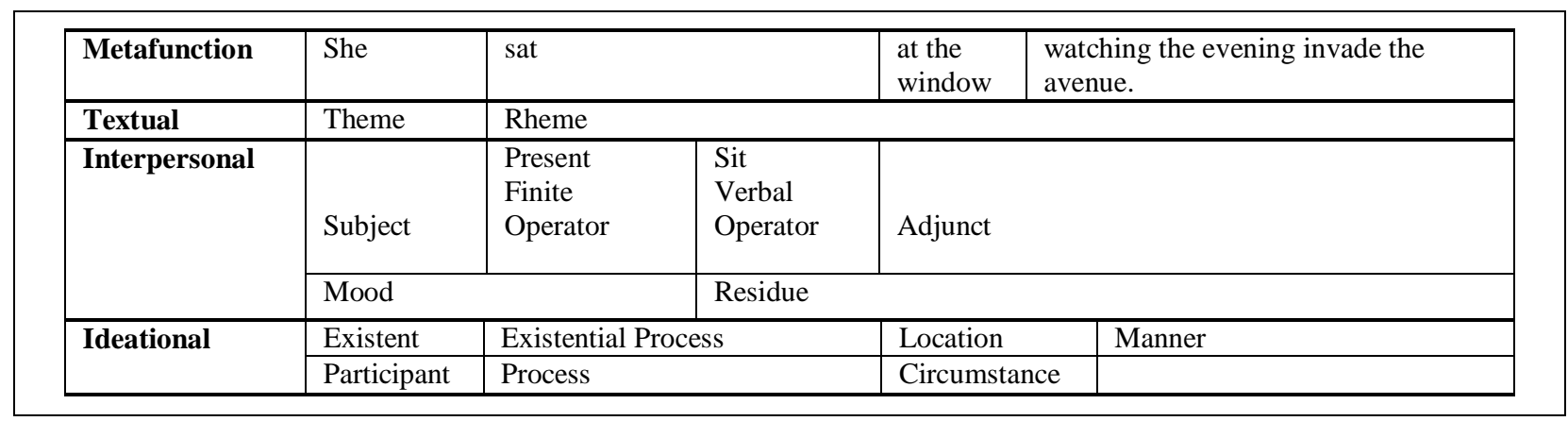

Figure 2. Saturation of sentence 1 using the three metafunctions

The interpersonal metafunction deals with establishing, facilitating, and maintaining social and interpersonal interactions between interlocutors, i.e., speaker and addressee. This metafunction concerns with social roles, degree of formality, intimacy, type of relationship, and distance as reflected by the modality. The building blocks of this semantic function configure as Subject, Finite Operator, Verbal Predicator, and Complement, in which the first two constitute Mood; and the last two, Residue. The Mood element is made of Subject and Finite Operator, and Residue is made of the Verbal Predicator, Complement, and Adjunct (Haratyan, 2011).
The ideational metafunction serves as the expression of the speaker's experience of the real world, including the inner world of his own consciousness. It consists of Participant, Process, and Circumstance. In this model, Halliday (1985, p. 53) uses grammatical resources at clause rank to interpret the inner and outer experience or "goings-on" of the word, as the domain of functions and meanings of the world through the systems of transitivity. It has two parts: the logical and the experiential functions. Central in the ideational metafunction is transitivity which, in Halliday's terms, is a major part in the experiential function of the clause that deals with the transmission of ideas, being 
processes or experiences: actions, events, processes of consciousness and relations.

Figure 2 illustrates the three metafunctions (Miller, 1997). The present study analyzed the text in terms of how the opening paragraph is saturated in a grid.

\section{Transitivity as author's ideological stance}

Transitivity manifests how certain choices encode the author's certain ideological posture as affected by the social and cultural institution (Fowler, 1986). He added that these linguistic codes cannot reflect reality neutrally and that they embody ideologies. Transitivity assigns semantic roles to participants such as Actor, Goal; Senser, Phenomenon; Carrier, Attribute; and circumstance including Cause, Location, Manner, Means, and Instrument. It also classifies processes such as doing, happening, feeling, sensing, saying, behaving, and existing. Figure 3 illustrates a model of transitivity (Simpson, 2004, p.26).

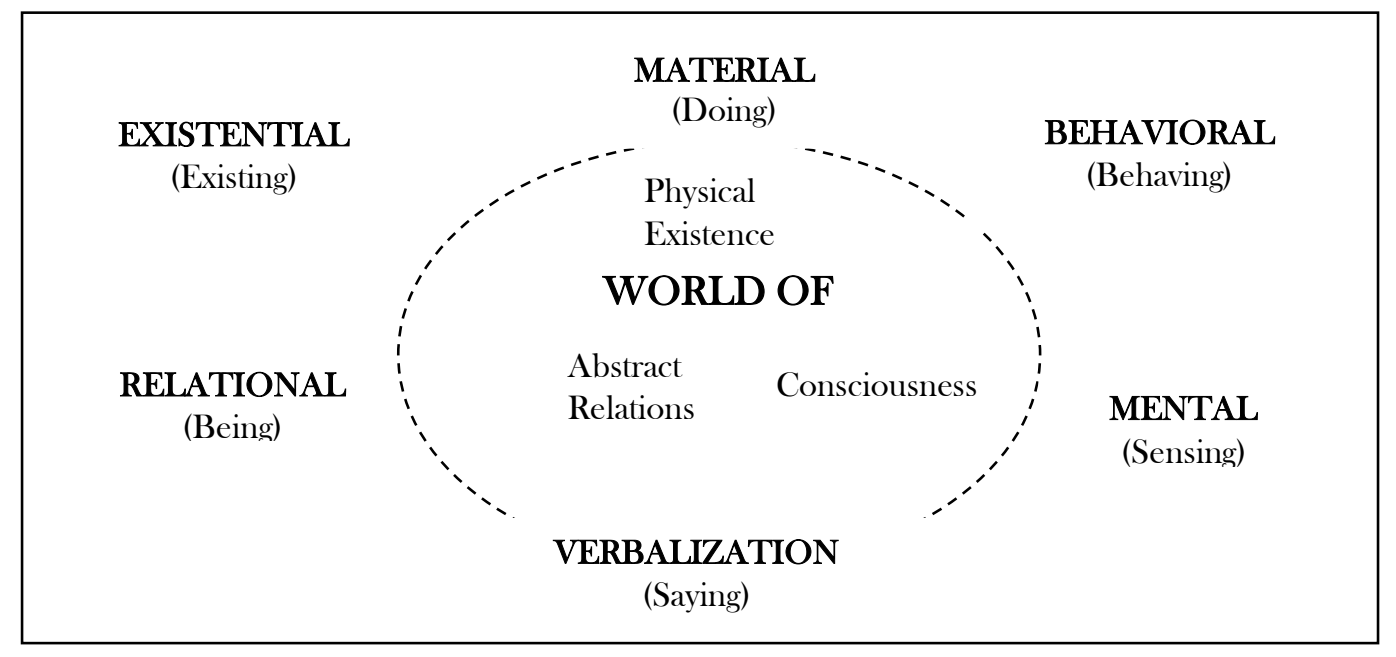

Figure 3. A model of transitivity

Below are the different process types and their characteristics. These process types have been used to categorize the transitivity of the six process types in the short story and the participants' semantic roles. This procedure may unravel what is foregrounded in the text and how the author used paradigmatic relation as a tool of defamiliarization. In this regard, the achievement of the aesthetic effects (preconceived or otherwise) using syntactic properties and semantic nuances can be appraised by the readers. This strategy is very helpful in establishing an objective evaluation and appreciation of the text as it elaborates its formal features and avoids giving illusive, impersonal, and subjective impressions. The present study accounts for the six process types shown below in its subsequent parts.

Table 1 characterizes the six process types in terms of their meanings, and, number and nature of participants as culled in the works of Bavali and Sadighi (2008), Cunanan (2011), and Halliday (1985, 1994, 2004). The table also shows the transitive roles of each of the nominal participants.

\section{FINDINGS}

To answer the three research questions, the subsequent parts show the results of the study. Table 2 and Table 3 present the distribution of the participants and their corresponding transitive roles. Table 4 shows how the use of individual words and phrases constitute the paradigmatic choices as evoked by their nuances.
Finally, thought presentation technique is described in terms of Free Indirect Discourse (FID).

Table 2 presents the choice of processes and transitive roles assigned to the primary participants, as shown by the frequency of use with corresponding percentages. The different processes are listed as they are used in the text.

Transitivity explored in the story by way of analyzing the different assigned semantic roles

The protagonist, Eveline, is largely assigned with mental and existential processes $(38.46 \%$ and $27.47 \%$, respectively). These transitive roles portray her throughout the story in terms of her mental state and her feeling of existence. Written in the SOC technique, on the one hand, the story presents the protagonist's acute sense of being and existence as reflected by a greater number of Mental and Existential processes. On the other hand, the small amount of Verbal and Behavioral process $(4.40 \%$ and $2.20 \%$, respectively), characterizes her passivity as she is hardly made to speak and express her feelings. The processes assigned to Eveline are enumerated below.

Material Processes: had dusted, had to work, would be married, would not be treated, gave, do marketing, had to meet, leaning, inhaling, could keep, kept moving, and gripped.

Mental Processes: watching, heard, looked, reviewing, wondering, would never see, had never dreamed, had never found, tried to weigh, don't see, look, felt, knew, 
did not find, was about to explore, remembered, had seen, felt elated, loves, felt pleasantly confused, had begun to like, noticed, remembered, could hear, knew, remembered, heard, remembered, mused, heard, wanted to live, knew, caught a glimpse, felt, and felt.
Relational Processes: was (tired), had, had, was, was, was, had, had no head, had any intention of buying, had hard work to keep, have, should be unhappy, and had a right to happiness.

Table 1. Summary of the process types (Bavali \& Sadighi, 2008; Cunanan, 2011; Halliday, 1985, 1994, 2004)

\begin{tabular}{|c|c|c|c|c|}
\hline Process type and their characteristics & $\begin{array}{c}\text { Category of } \\
\text { meaning }\end{array}$ & $\begin{array}{c}\text { No. of } \\
\text { inherent } \\
\text { participants }\end{array}$ & $\begin{array}{l}\text { Transitive } \\
\text { role of the } \\
\text { first } \\
\text { participant }\end{array}$ & $\begin{array}{l}\text { Transitive } \\
\text { role of the } \\
\text { second } \\
\text { participant }\end{array}$ \\
\hline $\begin{array}{l}\text { Material Process pertains to intentional or spontaneous } \\
\text { performance of an animate or inanimate, material processes, } \\
\text { externalized and concrete embody an action verb of doing or } \\
\text { happening, a doer is labelled as Actor and optional Goal, } \\
\text { affected by the process and circumstance that provides } \\
\text { details of the verb in terms of place, time, manner, condition, } \\
\text { etc. }\end{array}$ & $\begin{array}{l}\text { doing } \\
\text { (doing, } \\
\text { happening, } \\
\text { doing } \\
\text { to/with) }\end{array}$ & 1 or 2 & thing (actor) & thing (goal) \\
\hline $\begin{array}{l}\text { Existential process is about entities, events, or actions, } \\
\text { existential processes are about of existing with optional } \\
\text { representational function. }\end{array}$ & $\begin{array}{l}\text { being } \\
\text { (existence) }\end{array}$ & 1 or 0 & $\begin{array}{l}\text { thing or fact } \\
\text { (existent) }\end{array}$ & \\
\hline \multirow{2}{*}{$\begin{array}{l}\text { Relational Process is being classified into intensive, } \\
\text { attributive, identifying, circumstantial, and possessive, } \\
\text { relational processes are concerned with the processes of } \\
\text { description regarding the abstract relations. }\end{array}$} & $\begin{array}{l}\text { being } \\
\text { (attribute) }\end{array}$ & 1 & $\begin{array}{l}\text { thing or fact } \\
\text { (carrier) }\end{array}$ & \\
\hline & $\begin{array}{l}\text { being } \\
\text { (identity) }\end{array}$ & 2 & $\begin{array}{l}\text { thing or fact } \\
\text { (identified) }\end{array}$ & $\begin{array}{l}\text { thing or fact } \\
\text { (identifier) }\end{array}$ \\
\hline $\begin{array}{l}\text { Verbal Process stands on the border of mental and relational } \\
\text { processes, verbal processes are about of direct or indirect } \\
\text { report, with their linguistic representations of Sayer, Target, } \\
\text { and Verbiage. }\end{array}$ & saying & 1 & thing (sayer) & \\
\hline $\begin{array}{l}\text { Mental Process refers to three categories of cognition, } \\
\text { perception, and affection, mental processes are internalized } \\
\text { and consciousness type, are concerned with participants } \\
\text { labelled as Sensor and Phenomenon. }\end{array}$ & $\begin{array}{l}\text { sensing } \\
\text { (seeing, } \\
\text { feeling, } \\
\text { thinking) }\end{array}$ & 2 & $\begin{array}{l}\text { conscious } \\
\text { thing } \\
\text { (senser) }\end{array}$ & $\begin{array}{l}\text { thing or fact } \\
\text { (phenomenon) }\end{array}$ \\
\hline $\begin{array}{l}\text { Behavioral Process stands between material and mental } \\
\text { processes, the behavioral processes relate the physiological } \\
\text { and psychological behaviors such as breathing, coughing, } \\
\text { smiling, dreaming, and staring. }\end{array}$ & behaving & 1 & $\begin{array}{l}\text { conscious } \\
\text { thing } \\
\text { (behaver) }\end{array}$ & \\
\hline
\end{tabular}

Table 2. Comparison of distribution of process types of the major participants

\begin{tabular}{|c|c|c|c|c|c|c|c|c|c|c|c|c|c|c|}
\hline \multirow{3}{*}{$\begin{array}{c}\text { Major } \\
\text { Participant }\end{array}$} & \multicolumn{12}{|c|}{ Process Type } & \multirow{2}{*}{\multicolumn{2}{|c|}{ Total }} \\
\hline & \multicolumn{2}{|c|}{ Material } & \multicolumn{2}{|c|}{ Mental } & \multicolumn{2}{|c|}{ Relational } & \multicolumn{2}{|c|}{ Behavioral } & \multicolumn{2}{|c|}{ Verbal } & \multicolumn{2}{|c|}{ Existential } & & \\
\hline & f & $\%$ & f & $\%$ & $\mathbf{f}$ & $\%$ & f & $\%$ & $\mathbf{f}$ & $\%$ & f & $\%$ & f & $\%$ \\
\hline Eveline & 12 & 13.19 & 35 & 38.46 & 13 & 14.29 & 2 & 2.20 & 4 & 4.40 & 25 & 27.47 & 91 & 100.00 \\
\hline Frank & 11 & 31.43 & 1 & 2.86 & 4 & 11.43 & 0 & 0.00 & 12 & 34.29 & 7 & 20.00 & 35 & 100.00 \\
\hline $\begin{array}{l}\text { Eveline's } \\
\text { Father }\end{array}$ & 8 & 29.63 & 6 & 22.22 & 3 & 11.11 & 0 & 0.00 & 8 & 29.63 & 2 & 7.41 & 27 & 100.00 \\
\hline
\end{tabular}

Behavioral Processes: would not cry, and trembled. Verbal Processes: consented, answered, prayed, and sent a cry.

Existential Processes: sat, was going to go away, was being divided, had run away, leaving, had to rush out, elbowed her way, returning home, was about to leave, was to go away, used to visit, sat, had been laid up, continued to sit, was (in the close dark room), stood up, escape, stood, went, would be, steaming, could draw back, come, come, and set.

Frank, however, is portrayed as a Sayer, an Actor, or a Doer as shown by a greater number of Verbal and
Material process types $(34.29 \%$ and $31.43 \%)$. Also, there are very few instances $(2.86 \%$ and $0.00 \%)$ in the story in which he is assigned with Mental and Behavioral processes, suggesting that these states of his character are left unexplored. The process types assigned to Frank are enumerated below.

Material Processes: used to meet, would save, would give, would take, fold, would save, held, had done, seize, was drawing, and would drown.

Mental Processes: see

Relational Processes: (no entry) 
Behavioral Processes: was, had a home waiting, was awfully fond, and had started (as a deck boy).

Verbal Processes: sang, sang, used to call, had tales, told, told, said, was speaking, saying, called, was shouted, and called.

Existential Processes: was lodging, was standing, had been on, had sailed through, had fallen on his feet, had come over, and rushed.

Eveline's father, in addition, is characterized both as an Actor and a Sayer as shown by a greater number of assigned Material and Verbal processes (both $29.63 \%)$. Further, no Behavioral process $(0.00 \%)$ was assigned to him. The processes assigned to Eveline's father are enumerated below.

Material Processes: used often to hunt, would do, used to squander, wasn't going to give, would give, had quarrelled, made toast, and putting on.
Mental Processes: showed, had never gone, used to go, had found out, know, and would miss.

Relational Processes: was, was usually fairly bad, and could be very nice.

Behavioral Processes: (no entry).

Verbal Processes: used to pass, had begun to threaten, say, ask, had forbidden, said, read, and saying.

Existential Processes: was becoming old and strutting back.

Based on the foregoing empirical data, Joyce has strategically used semantic roles as linguistic features in establishing the three major characters. And being the proponent of the SOC technique, he has demonstrated a modernist approach to fiction by "portrayal of internal speech" (Leech \& Short, 2007, p. 270) more than the conflict that emanates from the conflict in the physical realm.

Table 3. Summary of distribution of other participants and their corresponding process types

\begin{tabular}{|c|c|c|c|c|c|c|c|c|c|c|c|c|c|c|}
\hline \multirow{3}{*}{$\begin{array}{l}\text { Participants and } \\
\text { Processes }\end{array}$} & \multicolumn{12}{|c|}{ Process Type } & \\
\hline & \multicolumn{2}{|c|}{ Material } & \multicolumn{2}{|c|}{ Mental } & \multicolumn{2}{|c|}{ Relational } & \multicolumn{2}{|c|}{ Behavioral } & \multicolumn{2}{|c|}{ Verbal } & \multicolumn{2}{|c|}{ Existential } & & \\
\hline & f & $\%$ & f & $\%$ & f & $\%$ & $\mathbf{f}$ & $\%$ & f & $\%$ & f & $\%$ & \multicolumn{2}{|c|}{ Total } \\
\hline \multicolumn{15}{|l|}{ Other Human } \\
\hline Participants & 9 & 12.86 & 8 & 11.4 & 16 & 22.86 & 1 & 1.43 & 4 & 5.71 & 7 & 10.00 & 45 & 64.29 \\
\hline \multicolumn{15}{|l|}{ Eveline's Body } \\
\hline Parts & 3 & 4.29 & 0 & 0.0 & 1 & 1.43 & 0 & 0.00 & 0 & 0.00 & 0 & 0.00 & 4 & 5.71 \\
\hline Inanimate Things & 1 & 1.43 & 0 & 0.0 & 2 & 2.86 & 1 & 1.43 & 2 & 2.86 & 5 & 7.14 & 11 & 15.71 \\
\hline $\begin{array}{l}\text { Location } \\
\text { References }\end{array}$ & 1 & 1.43 & 0 & 0.0 & 3 & 4.29 & 0 & 0.00 & 1 & 1.43 & 2 & 2.86 & 7 & 10.00 \\
\hline Time References & 0 & 0.00 & 0 & 0.0 & 2 & 2.86 & 0 & 0.00 & 0 & 0.00 & 1 & 1.43 & 3 & 4.29 \\
\hline TOTAL & 14 & 20.00 & 8 & 11.4 & 24 & 34.29 & 2 & 2.86 & 7 & 10.00 & 15 & 21.43 & 70 & 100.00 \\
\hline
\end{tabular}

Table 3 shows the processes types assigned to the three major participants: (a) other human participants, (b) Eveline's body parts, (c) location references, and (d) time references. Generally, these minor processes were primarily assigned with Relational process $(35.56 \%)$. Specifically, the other human participants or characters were assigned with Relational and Material processes (22.86\% and $12.86 \%$, respectively). Eveline's body parts were assigned Material processes (4.29\%), the inanimate things were mostly assigned Existential processes $(7.14 \%)$; the location references were assigned Relational processes (4.29\%), and time references were assigned Relational processes $(2.86 \%)$. The process types are enumerated and arranged as they appear in the text of the story.

The other human participants are as follows: People, the man, they (children), the children (Devines, the Waters, the Dunns, and little Keogh the cripple), a man from Belfast, Ernest, Keogh, they (Eveline and her siblings), her mother (Eveline's), Tizzie Dunn, (the) Waters, the priest, they (Eveline's co-workers), Miss Gavan, people (at the store), these ladies (customers), people (in Buenos Aires), Ernest, Harry, two young children (Ernest and Harry), they (Eveline and Frank), people (in the community), they (Eveline and her family), the children (Eveline and her siblings), the organ-player, and damned Italians. The process types assigned to the Other Human Participants are : passed, passed, used to play, used to play, bought, played, was, saw, used to keep nix, call out, seemed to have been rather happy, were, were growing up, was, was dead, was alive, was, had gone back, had been, is, found, say, would be glad, had, had, listening, are waiting, would treat, had been, liked, was, sent up, was in business, was down, got, had been left, went to school, had come to know, were courting, knew, had all gone, laugh, had been given, had been ordered, and coming over.

The participants about Eveline's body parts are as follows: head, nostrils, her hands, and her eyes; and the process types: was leaned, was, clutched, and gave. The process types assigned to Inanimate Things are: dust, the priest' yellowing photograph, the pitiful vision of her mother's life, her mother's voice (Eveline), her (Eveline's) duty, it (church organ), their passage (Eveline and Frank), her distress, a bell, all the seas of the world, and it (eloping with Frank); and the corresponding process types are: came, hung, laid, saying, was, had been booked, awoke, clanged, should come, tumbled, and was impossible.

The participants pertaining to location references are: a field, her (Eveline's) place, there (at the store), it (home in distant country), the station, the boat, and the 
boat; and the corresponding process types are: used to be, would be filled up, were, would not be, was, lying, and blew.

Lastly, the participants pertaining to Time References are that (Eveline's childhood), it (Frank having met Eveline), and her time (Eveline's); and their corresponding process types are: was, seemed, and was running out.

\section{Paradigmatic choices explored in exemplifying the persona's point of view}

The first three paragraphs of the story show some examples of paradigmatic features. In presenting the protagonist's "mental picture of reality" (Halliday, 1994, p. 106), Joyce skilfully contrived deviations in the flow of information in the text through non-habitualized rendering of transitive roles to the participants. To achieve this technique, Joyce has demonstrated Eveline's psychological paralysis in the opening paragraph by juxtaposing and contrasting her passivity and the vitality of the evening as it spreads in the avenue.

Table 4 shows the comparison of the nuanced and the conventional presentation of the opening paragraph. As shown in the text, Joyce uses Existential process sat, Mental process watching, and Material process invade. Noticeably, the passive was leaned is used instead of its active counterpart. The two syntactic nuances suggest that the persona is made to appear as she seems not to be in control of the situation, a foreshadowing of susceptibility or vulnerability. Also, "in her nostrils was the odour" had been chosen instead of "she smelled the odour" of the dusty cretonne. And 'she was tired' was used instead of "she felt tired" to emphasize Eveline's weakness, passivity, and helplessness which are instances that underscore her incapability of feeling, which heightens paralysis as the motif of the story.

Table 4. Comparison of the Nuanced and Conventional Presentation of the Opening Paragraph

\begin{tabular}{ll}
\hline Nuanced Presentation & Conventional Presentation \\
\hline $\begin{array}{l}\text { She sat at the window watching the evening invade the } \\
\text { avenue. }\end{array}$ & $\begin{array}{l}\text { Eveline sat at the window watching the evening invade the } \\
\text { avenue }\end{array}$ \\
\begin{tabular}{ll} 
Her head was leaned against the window curtains and in her & She leaned her head against the window curtains and she \\
nostrils was the odour of dusty cretonne. & smelled the odour of dusty cretonne. \\
She was tired. & She felt tired. \\
\hline
\end{tabular}
\end{tabular}

The Free Indirect Discourse (FID) in thought and speech presentation described the blend between transitivity roles and lexico-syntactic choices

Joyce uses FID to suggest or reveal to the reader the bits and pieces of thoughts and feelings of the protagonist in the story. Through this technique, he makes the reader piece together Eveline's repressed dilemma as she timidly weighs her decision of escaping from the drudgery of her daily routines to be with her suitor in the distant, uncertain life across the seas. Passive and unable to decide, she cannot let go of her past life that relates to her mother's death. Like a "helpless animal", she is emotionally and spiritually paralyzed to pursue her dreams away from her abusive, violent father and the prison she calls her home. Using the omniscient point of view, Joyce intensifies Eveline's character with the use of internal and subjective time to magnify her timidity and powerlessness. In this regard, FID helps in "describing" and "accessing a character's thoughts" that is achieved by "embedding a character's speech or thoughts into an otherwise-third person narrative" which, in effect, enables the reader to grasp the thoughts of the narrator and of the character as well (Gingerich, 2012).

\section{DISCUSSION}

The Dubliners, Joyce's collection of 15 short stories, is regarded to be one of the best collections of fiction in English (Li, 1999). This collection of stories deals with 'realistic and impressionistic studies of the life, thoughts, dreams, aspirations, and frustrations of diverse inhabitants in the Irish capital" (Liu, 2001, p. 492;
Wang, 2014). The Dubliners "is a powerful work containing some of the most finely wrought short stories in English" (O'Halloran, 2007, p. 227). The anthology emphasizes paralysis or sense of stagnation as its overarching theme. How Joyce achieved such aesthetic effect through lexical choices and syntactic manipulation has been the main goal of the present study. Consistent with the stance of Jones (2010), this paper advocates that "creativity is located not in language per se, but in the strategic ways people use language in concrete situations to stimulate social change" (p.467).Indeed, the quality of this anthology of short stories has found its rightful place in the syllabi of English language and literature as what $\mathrm{Ab}$ Rashid, Vethamani, and Rahman (2010) acknowledge.

Skilfully written, Eveline and the rest of the stories in this anthology can be a material and springboard for teaching literature through linguistic means, an approach, which according to (Fowler, 1984), has been challenged by both literary critics and linguists. Eveline, being one of James Joyce's exemplar short stories in this anthology, has been considered remarkable by many scholars for its literary complexity (Attridge, 2004; Chatman, 1969; Culler, 1975; Hart, 1969; Leech \& Short, 1981; O'Halloran, 2007; Short, 2006; Stubbs, 2005; Toolan, 2001). More so, the works of O'Halloran (2007) and Chun (2011) have confirmed that Eveline foregrounds processes that deal with inaction, deliberately presented in passive form as metaphors of paralysis, with thoughts, feelings, and recollections dominating the text-these characteristics have been confirmed in the foregoing analysis. 
Similarly, Zhang discusses Joyce's craftsmanship in using paralysis by highlighting some words as metaphorical elements. According to Zhang, "dust" was used by Joyce in the story to "symbolize the dry, sterile, and dull life of Dublin" (1994, p.23). Furthermore, Zhang (1994, p.27) further describes the use of this method in the latter part:

"All the seas of the world tumbled about her heart. He was drawing her into them: he would drown her. She gripped with both hands at the iron railing".

The tumbling seas in the protagonist's interior monologue also suggest the unspeakable fears of the protagonist just as the iron railings serve as images of the awaiting uncertainties in the distant land of Buenos Aires (Sang, 2010). The skilful symbolism in revealing the realizations of Eveline proves the subtle yet engaging effect of the SOC technique in dramatizing the helplessness of young people in Dublin at that time (Wang, 2014).

With a high level of craftsmanship, Joyce lets his readers get into the mind of the persona without any much obvious linguistic signal, as illustrated in the use of the FID. To achieve such a stylistic effect, the persona does it very smoothly with a very short opening statement in the second paragraph: "Few people passed."

Also, it is evident that the name of the protagonist has been delayed until the ninth paragraph. With this strategy, a close reading of the story is encouraged to make the readers relive the experiences of the protagonist and engage them as active participants instead of passive observers who are led to see the events unfolding. Moreover, the readers can see the events through the mind and worldview of the character.

In effect, Joyce has made reading the story more engaging. Furthermore, Joyce uses the flashback not just a recollection of the past but presents events as they run in the mind of the protagonist. In doing so, he creates a make-believe situation to make it appear so real. Such effect is achieved by using for 16 times the definite article the in the second paragraph.

The subsequent paragraph is introduced with a sentence that consists of the word "Home!". This oneword sentence immediately follows a flashback of 226 words. It comes as a jolt to the readers about the here and now of the moment-if not to share with the protagonist's own disbelief or coming back to her senses. In addition, her recollection of some familiar images in her home does not only help in establishing the physical aspects of the setting of the story but even more intensifies the dilemma and her inability in making a decision to move on.

To make a full circle, Joyce (1991, p.36) pushes the story to its end with equal intensity and depth as he introduces it. The final part, though it is open-ended, leaves the reader petrified with pity and in great awe:

He rushed beyond the barrier and called to her to follow.

He was shouted at to go on, but he still called to her. She set her white face to him, passive, like a helpless animal.
Her eyes gave him no sign of love or farewell or recognition.

\section{CONCLUSION}

This paper has discussed the importance of using a Systemic Functional framework to appraise thought presentation, an elusive element in fiction. It has also shown how characterization in modernist fiction poses challenges to the uninitiated readers, particularly to those who study English either as a second or a foreign language, especially with modernist fiction. The study has stressed that such difficulty cannot be solved simply by way of structural analysis that is not sensitive to context. However, using a grammatical framework that is oriented to the semiotic aspect of language may provide tangible guideposts to students of literature. This kind of framework enriches the students' encounter with the array of linguistic choices that authors have at their disposal. Furthermore, making language work in reading literary texts may reward students and motivate them to explore the richness of the confluence of a text and its context. This paper has also suggested the potential of helping students to extend their appreciation of language as a tool for making them informed and empowered consumers of texts, for their personal needs, and for the benefits of others in society. This kind of empowerment may then serve as a catalyst for personal and social transformation. In doing so, the study of literature and language remains timely, relevant, motivating, and rewarding.

This paper has demonstrated how transitivity, paradigmatic choices, and thought presentation can be analyzed by presenting how they occur in the text. Specifically, this paper has shown how the following tasks can be done in an ESL or EFL class.

1. Analyzing transitive roles can be made viable by categorizing process types, participants, and circumstances at the ideational level. This activity provides the students with a deeper appreciation not only of the different process types but also of the worldview, perspective, or point of view of the characters.

2. Categorizing the different paradigmatic choices can be a rewarding language and literature activity in appropriating a fresh, rich, and dynamic reading experience which renders a deeper appreciation of the craft, originality, and ingenuity of an author.

3. Using different techniques in speech and thought presentation could be made feasible by attending to how an author deviates from the habitualized ways of rendering thoughts, feelings, and expressions in some singular ways giving the reader a better perception and appreciation of what in the realm of human experience and existence deems to be familiar or perceptible. 


\section{ACKNOWLEDGMENT}

The author wants to thank the Faculty and Staff Development of the Bulacan State University for encouraging the researcher to pursue this study and Dr. Venancio L. Mendiola of the Philippine Normal University - Manila for sustaining his interest in doing works in stylistics.

\section{REFERENCES}

Ab Rashid, R., Vethamani, M. E., \& Rahman, S.B.A. (2010). Approaches employed by teachers in teaching literature to less proficient students in form 1 and form 2. English Language Teaching, 3(4), 87.

Akyel, A. (1995). Stylistic analysis of poetry: A perspective from an initial training course in TEFL. TESL Canada Journal, 13(1), 63-73.

Amase, L., Tsavmbu, A., \& Kaan, A. (2014). The relationship between language, literature, teacher effectiveness and quality education. International Journal of Social Science Research, 2(1), 29-38.

Arnold, N, (2009). Online extensive reading for advanced foreign language learners: An evaluation study. Foreign Language Annals, 42, 340-366.

Attridge, D. (Ed.) (2004). The Cambridge companion to James Joyce (2nd ed). Cambridge: Cambridge University Press.

Baldick, C. (Ed.). (2001). The concise Oxford dictionary of literary terms. London: Oxford University Press.

Bavali, M. \& Sadighi, F. (2008). Chomsky's universal grammar and Halliday's systemic functional linguistics: An appraisal and a compromise. Journal of Pan-Pacific Association of Applied Linguistics, 12(1), 11-28.

Bell, T, (2013). Innovative approaches to teaching literature in the world language classroom. MultiTasks, MultiSkills, MultiConnections, (pp. 127-139). Richmond, VA: Robert M. Terry

Blake, N. F. (1990). An introduction to the language of literature. London: Macmillan

Carter, R. A. \& Long, M. (1991). Teaching literature. Essex: Longman.

Chatman, S. (1969). 'New ways of analysing narrative structure, with an example from Joyce's Dubliners', Language and Style, 2(1), 3-36.

Choudhary, S. (2016). A literary approach to teaching English language in a multicultural classroom. Higher Learning Research Communications, 6(4). Retrieved from: https://files.eric.ed.gov/fulltext/EJ1132741.pdf

Chun, Y. (2011). A portrait of paralysis: A stylistic reading of 'Eveline'. Sino-US English Teaching, 8(5), 337-342.

Collie, J. \& Slater, S. (1987). Literature in the language classroom. Cambridge: Cambridge University Press.

Cox, B. (1991). Cox on Cox: An English curriculum for the 1990. California: Hodder and Stoughton.
Culler, J. (1975). Defining narrative units, In R. Fowler (Ed.) Style and Structure in Literature (pp.12342). Oxford: Blackwell.

Cunanan, B. (2011). Using transitivity as a framework in a stylistic analysis of Virginia Woolf's Old Mrs. Grey. Asian EFL Journal, 54, 69-79.

Devardhi, J. \& Nelson, D. (2013). Stylistic analysis based on Formalism: Metalinguistic reflection of Whitman's “One's Self I Sing." Elite Research Journal of Education and Review, 1(2), 6-11.

Edmondson, W.(1997). The role of literature in foreign language learning and teaching: Some valid assumptions and invalid arguments. In A Mauranen. \& K. Sajavaara (eds.), Applied linguistics across disciplines. AILA Review, 12 1995/6. 42-55.

Fakeye, D. \& Temitayo, A. (2013). Enhancing poetic literature instruction through stylistic and thematic approaches. Studies in Literature and Language, 6(2), 50-55.

Fogal, G. (2015). Pedagogical stylistics in multiple foreign language and second language contexts: A synthesis of empirical research. Language and Literature, 24, 54-72.

Fowler, R. (1984). Studying literature as language. Dutch Quarterly Review of AngloAmerican Letters, 14(3), 171-184.

Fowler, R. (1986). Linguistic criticism. London: Oxford University Press.

Fowler, R. (1996). Linguistic criticism (2nd ed). Oxford: Oxford University Press.

Fowler, R. (2006). The Routledge dictionary of literary terms. London: Routledge.

Gaies, S. (1979). Linguistic input in formal second language learning, TESOL Quarterly, 13(1), 41-50.

Gingerich, J. (2012). The benefits of free indirect discourse. Retrieved on February 14, 2018 from https://litreactor.com/columns/the-benefits-of-freeindirect-discourse

Gonzales, W. \& Flores, E. (2016). Stylistics in the Southeast Asian ESL or EFL classroom: A collection of potential teaching activities. TESOL International Journal, 11(1), 96-107.

Gunn, D. (2004). Free and indirect discourse and narrative authority in Emma. Narrative 12, 35-54

Hall G. (2007). Stylistics in second language contexts: A critical perspective. In G. Watson \& S. Zyngier (eds.) Literature and stylistics for language learners (pp. 3-14). Palgrave Macmillan, London.

Hall, G. (2005). Literature in language education. New York: Palgrave Macmillan.

Halliday, M. A. K. (1970). A course in spoken English: Intonation. Oxford: Oxford University Press.

Halliday, M.A.K. (1978). Language as social semiotic: The social interpretation of language and meaning. London: Edward Arnold.

Halliday, M.A.K. (1985). Systemic background. In J. D. Benson, \& W. S. Greaves, (Eds). Systemic perspectives on discourse, volume 1. Selected theoretical papers from the 9th International 
Systemic Workshop (pp. 1-15). Norwood, NJ: Ablex Publishing Corporation.

Halliday, M.A.K. (1994). An introduction to functional grammar (2nd ed.). London: Edward Arnold.

Halliday, M.A. K. (2004) An introduction to functional grammar (3rd ed.). Rev. Matthiessen C. London: Edward Arnold.

Haratyan, F. (2011). Halliday's SFL and social meaning. 2nd International Conference on Humanities, Historical and Social Sciences IPEDR17, 260-264.

Hart, C. (1969). 'Eveline'. In C. Hart, James Joyce's 'Dubliners' (pp. 48-52). London: Faber and Faber.

Hişmanoğlu, M. (2005). Teaching English through literature. Journal of Language and Linguistic Studies, 1(1), 53-66.

Huang, M. (2014). Ten writers who use the stream of consciousness better than anybody else. Retrieved on January 24, 2017 from https://qwiklit.com/2014/03/22/10-writers-whouse-stream-of-consciousness-better-than-anybodyelse/

Inyang, G. (2009). Linguistic-stylistic technique and the effective teaching and learning of poetry in Nigerian senior secondary schools. An International Multi-Disciplinary Journal, Ethiopia, 3(2), 78-91.

Jakobson, R. (1960). Linguistics and poetics: Closing statement. Style in Language. MIT Press, Cambridge, MA.

Jones, R. (2010). Creativity and discourse. World Englishes, 29(4), 467-480.

Joyce, J. (1991). Dubliners. New York: Penguin Group.

Koutsompou, V. (2015). The use of literature in the language classroom: Methods and aims. International Journal of Information and Education Technology, 5(1), 74-79.

Lazar, G. (1993). Literature and language teaching. Cambridge: Cambridge University Press.

Lee, H. (2006). The two principles of representation: Paradigm and syntagm. Kansai University Journal of Foreign Language Education and Research, 11, 79-88.

Leech, G. \& Short, M, (1981), Style in fiction. London: Longman.

Leech, G. \& Short, M. (2007). Style in fiction (2nd ed). Edinburg Gate: Pearson Educational Limited.

Leech, G. (1969). A linguistic guide to English poetry. London: Longman.

Li, L. (1999). From sister the dead to Dubliners: An analysis of Dubliners' artistic characteristics. Foreign Language Review, 1, 18-22.

Liu, B. (2001). A short history of English literature. Zhengzhou: Henan People's Publishing House.

Lončar-Vujnović, M. (2013). Stream of consciousness technique and modern novel: Psychological and methodological perspectives on language learning. IOSR Journal of Research \& Method in Education, (2)2, 69-76.
Maley, A. (1989). Down from the pedestal: Literature as resource. In R. Carter, R. Walker \& C. Brumfit (Eds.), Literature and the learner: Methodological approaches. London: Modern English Publications and the British Counsel.

Malmkjær, K. (Ed.). (1991). The linguistics encyclopaedia. London: Routledge.

Malmkjær. K. (Ed.). (2002). The linguistics encyclopaedia, $\left(2^{\text {nd }}\right.$ ed.). London and New York: Routledge.

Matthiessen, C. (1995). Lexico-grammatical cartography: English systems. Tokyo: International Language Science Publishers.

Miller, T. (Ed.). (1997). Functional approaches to written text: Classroom applications. Washington D.C.: English Language Programs, United States Information Agency.

Modern Languages Association. (2007). Foreign languages and higher education: New structures for a changed world. Retrieved on March 16, 2018 from https://www.mla.org/Resources/Research/SurveysReports-and-Other-Documents/TeachingEnrollments-and-Programs/Foreign-Languagesand-Higher-Education-New-Structures-for-aChanged-World

Norgaard, N., Busse, B. \& Montoro, R. (2010). Key terms in stylistics. London: Continuum International Publishing Group.

Nunan, D. (2009). Second language teaching and learning. Cengage Learning: Hong Kong.

O'Halloran, K. (2007). The subconscious in James Joyce's Eveline: A corpus stylistic analysis that chews on the Fish hook. Language and Literature, 16(3), 227-244.

Omaggio Hadley, A. (2001). Teaching language in context. Boston: Heinle.

Pathan, M.M. \& Al-Dersi, Z. E.M. (2013). Investigating the role of short-stories in overcoming the problems faced by the Libyan EFL learners in reading comprehension skill. The Criterion: An International Journal in English, 12.

Povey, J. (1972). Literature in TESL programs: The language and the culture. In H. Allen \& R. Campbell (ed.) Teaching English as a second language. New York: McGraw-Hill.

Rosenblatt, L. (1995). Literature as exploration. New York: The Modern Language Association of America.

Sadighi, F. \& Bavali, M, (2008). Chomsky's universal grammar and Halliday's systemic functional linguistics: An appraisal and a compromise. Journal of Pan-Pacific Association of Applied Linguistics, 12(1), 11-28.

Sahlgren, M. (2006). The word-space model: Using distributional analysis to represent syntagmatic and paradigmatic relations between words in high-dimensional vector spaces (Unpublished doctoral thesis). Department of Linguistics, Stockholm University, Sweden. 
Sang, Y. (2010). An analysis of stream-ofconsciousness technique in to the lighthouse. Asian Social Science, 6(9), 173-179.

Santhi, T.K. (2012). Teaching language through literature. Journal of English and Literature, 2(2), 17-21.

Sebeok. T. (Ed.). (1960). Style in language. New York: The Technology Press of Massachusetts Institute of Technology and John Wiley \& Sons.

Şeker, E. (2013). Paradigmatic, syntagmatic, and contextual relations in Araby. International Journal of Research in Social Sciences, 3(2), 1746.

Shaumyan, S.K. (1998). Two paradigms of linguistics: The semiotic versus non-semiotic paradigm. Web Journal of Formal, Computational and Cognitive Linguistics, 2, 1-72.

Short, M. (1995). Understanding conversational undercurrents in The Ebony Tower by John Fowles. In P. Verdonk \& J.J. Webber (Eds.) Twentieth century fiction: From text to context (pp. 45-62). Routledge: London.

Short, M. (2006). Band 6: The art of English 2, Literary Quality in Fiction (CD-ROM). Milton Keynes: The Open University.

Shrum, J. \& Glisan, E. (2010). Teacher's handbook: Contextualized language instruction. Boston: Heinle.

Silberstein, S. (1994). Techniques and resources in teaching reading. New York: Oxford University Press.

Simpson, P. (2004). Stylistics: A resource book for students. London: Routledge.

Simpson, P. (2012). Twenty years of language and literature: A reflection. Language and Literature, 21(1), 12-17.

Sivasubramaniam, S. (2006). Promoting the prevalence of literature in the practice of foreign and second language education: Issues and insights. Asian EFL Journal, 8(4), 254-273.

Stubbs, M. (2005). Conrad in the computer: Examples of quantitative stylistic methods. Language and Literature 14(1), 5-24.

Suzuki, R. (2001). A stylistic analysis and interpretation of Thomas Hardy's the Going. Paper read at the 44th Annual Meeting of the Thomas Hardy Society of Japan, Chuo University, Tokyo.

Toolan, M. (2001). Narrative: A critical linguistic introduction (2nd ed.). London: Routledge.

Trask, R. L. (1993). A dictionary of grammatical terms in linguistics. London and New York: Routledge.

Traugott, E. \& Pratt, M. (1980). Linguistics for students of literature. New York: Harcourt Brace Jovanovich.

Tunçel, R. (2009). The effect of short story reading through constructivist activities on the language development of primary school students. Retrieved from

http://www.sosyalarastirmalar.com/cilt2/sayi6pdf/t uncel_ridvan.pdf

Upreti, K. (2012). Teaching short stories: Challenges and issues (Unpublished master's thesis). Tribhuvan University, Nepal.

Van, T.T.M. (2009). The relevance of literary analysis to teaching literature in the EFL classroom. English Teaching Forum, 3, 2-9.

Verdonk, P. (2002). Stylistics. Oxford: Oxford University Press.

Violetta-Irene, K. (2015). The use of literature in the language classroom: Methods and aims. International Journal of Information and Education Technology, 5(1), 74-79.

Wang, X. (2014). An appreciation of James Joyce's writing methods in 'Eveline'. US-China Foreign Language, 12(5), 411-414.

Watson, G. \& Zyngier, S. (Eds.) (2007). Literature and stylistics for language learners. London: Palgrave Macmillan.

Weber, J.J. (1996). The stylistics reader: From Jakobson to the present. London: Arnold.

West, A. (1994). The centrality of literature. In S. Brindley (Ed.), Teaching English. London: Routledge.

Widdowson, H. G. (1975). Stylistics and the teaching of literature. London: Longman.

Zhang, K. W. (1994). Survey of British and America. Changchun: Jilin Science and Technology Publishing Press. 